\title{
Strategic Analysis for LNG Vehicle Filling Business in the Low Carbon Economy \\ Yuan-Gao ZHANG ${ }^{1, a,{ }^{*}}$
}

${ }^{1}$ School of Economics Management, China University of Petroleum, Shangdong266580, China. a317171037@qq.com

${ }^{*}$ Corresponding author

Key words: Low carbon economy, LNG, vehicle filling business, development strategy

\begin{abstract}
LNG vehicle filling business has developed rapidly in recent years, and is becoming a new profit increasing point, but its development environment changes quickly and increasing complex. There are many difficulties in the process of development. It is necessary to review its development strategy planning. Based on the SWOT analysis of this paper, it is suggested that the LNC vehicle filling business should chose fast penetration strategy, namely, quickly occupying the market in the shortest time, which savings business energy for the future development of our country's cleaner energy.
\end{abstract}

\section{Introduction}

Our country has qualified to vigorously promote the application of LNG vehicle from the aspects of market demand, gas support, technical support and policy environment. Domestic LNG vehicle industry has developed rapidly, and has become an economic hot spots and formed increasingly competitive market competition pattern with state-owned, private and foreign companies participated jointly.

In 2011, according to data, the quantity of serving LNG vehicles is about 60,000 in our country, while the amount of highway passenger vehicles is 20,000, trucks is about 35,000 and public buses is about 6,000. China Road Transport Association indicated that the top three oil companies, Xinao Eenergy, Xinjiang Guanghui and other companies have planned to build 5000 new LNG filling station during the "twelfth five year", and the conservative estimates of the amount of the new constructed station is about 2500. According to the predication of China Road Transport Association, the amount of serving LNC vehicles in the field of national intercity passenger transport, freight transport and public transport will be more than 250,000 by 2015 . By 2020 , the figure will rise to about 1 million. If the vehicle gas prices can be maintained stably at the current level, LNG vehicles are expected to be applied to long-distance passenger transport, freight transport and public transport widely. Based on the SWOT analysis of gas filling business sector, the paper is expected to clearly identify the development opportunities and threats to find the development strategy that is more in line with the competitive situation.

\section{SWOT Analysis of LNG Vehicle Filling Business}

The competitive advantage of LNG vehicle filling business is bound up with the competitiveness of LNC vehicle corresponding to other types of cars. Therefore, it is necessary to analysis the merits and demerits of LNG vehicle relative to other types of cars. 


\section{The Advantage Analysis of LNG Vehicle}

\section{Security advantage analysis.}

LNG is liquid and its filling feed is fast, which can decrease the construction of LNG station compared with the gaseous CNG. It is more suitable for the large intercity passenger cars and heavy trucks. Moreover, LNG automobile is safer than CNG automobile in traffic accidents. The break of gas cylinder in CNG automobile may lead to explosion and combustion, while the break of insulation gas cylinder may result in LNG flowing out. But vaporizing Liquefied Natural Gas which is minus 162 degree need to absorb a large amount of thermal energy, and it could not explode immediately. Therefore, LNG automobile is safer than CNG automobile. The ignition point of vaporized $\mathrm{LNG}$ is $650^{\circ} \mathrm{C}$, which is higher than that of diesel ignition point $\left(260^{\circ} \mathrm{C}\right)$. More energy is needed to ignite vaporized LNG than to ignite gasoline and diesel. So LNG is hard to ignite compared with the regular gasoline and diesel. The relative density of vaporized LNG is 0.47 or so, which is only half of the air density and much lighter than air. What's more, its vaporizing temperature is minus $162^{\circ} \mathrm{C}$ under the ordinary pressure. So the slight leakage will diffuse immediately under normal conditions. It is different from the gasoline and diesel which is easy to form a hazard. The explosion limit of vaporized LNS is $4.7 \% \sim 15 \%$, while the diesel is $0.5 \%$ 4.1\%. LNG is difficult to reach the condition of explosion. Therefore, LNG vehicles are safer than gasoline and diesel vehicles.

\section{Reliable advantage analysis}

The reliable advantage of LNG vehicles lies in its good cold-start performance, strong endurance ability and less carbon deposition in cylinder. In winter, the fuel tank of diesel vehicles will be frozen at 25 degree blew zero, which is hard to start and is short of power. A domestic motorcade runs long-distance transportation business, a line to and from Shanxi and Inner Mongolia. In the actual operation, they have found that the burning explosion accident rate of LNG vehicles is zero, and it is easy to launch in the low temperature environment. Its power is not affected by the weather. Compared with diesel vehicles, the reliability and convenience of LNG vehicles is more outstanding. In addition, due to the LNG burning completely, no carbon deposition and no lubricating oil dilution, it can effectively reduce the abrasion of parts, and reduce the failure rate and prolong the service life of engine. So the reliability of the LNG vehicle is better. At the same time, the natural gas is stored in liquid form in storage tank of LNG vehicle. The density of LNG at minus $162{ }^{\circ} \mathrm{C}$ is 600 times the density of the natural gas in the standard state, and is 3 times the density of the same volume $\mathrm{CNG}$, which greatly increase mileage of LNG vehicle and improve the reliability of its range.

\section{Economic advantage analysis}

As the efficiency of LNG vehicle, it is mainly reflected in the operation that the fuel cost is low. Taking the M3000, 340 horsepower automobile made in Shanxi Delong for example, buying a new M3000 LNG car will cost 520,000 Yuan, but a new diesel car in same model will cost 350,000 Yuan. There is 170,000 Yuan price difference. The cost of LNG car and diesel car are compared in the following table.

Table 1The cost of two kinds of cars comparing

\begin{tabular}{|c|c|c|c|}
\hline Automotive fuel & Fuel price & $\begin{array}{c}\text { Consumption per } \\
\text { hundred kilometers }\end{array}$ & $\begin{array}{c}\text { Fuel cost per } \\
\text { hundred kilometers }\end{array}$ \\
\hline diesel & 7 Yuan/litre & 33 litre & 231 Yuan \\
\hline LNG & 5.8 Yuan $/ \mathrm{kg}$. & $28 \mathrm{~kg}$. & 162.4 Yuan \\
\hline
\end{tabular}


Compared with diesel car, the LNG car in same model can save 68.6 Yuan in every hundred kilometers. The saving rate was $29.7 \%$ and the fuel cost is reduced significantly. Taking a transport company owned 132 LNG vehicles for example, every LNG car can save 120,000 Yuan in fuel cost than diesel car according to the calculation that a LNG car running 180,000 kilometers per year. It will take a year and a half to make up for the car price difference. The longer the mileage is, the more the money is saved. It can save fuel cost about 15,840,000 Yuan a year and the economic effect is obvious.

\section{Environmental advantage analysis}

As a kind of clean energy, LNG is more and more popular with the users in recent years. Natural gas was conducted purification treatment strictly before liquidation. Heavy hydrocarbon, sulfide, carbon dioxide, water and other impurities were removed out, so the automobile exhaust pollution is small. It is friendlier to the environment than $\mathrm{CNG}$ vehicle.

\section{The Disadvantage Analysis of LNG Vehicle}

The disadvantage of LNG vehicle is mainly manifested in unstable gas price, the problem of fuel consumption, less filling stations, the restriction of range, the problem of gas cylinder safety, after-sales service, and the difficulties of air-entrapping and standard stand construction.

\section{Unstable LNG supply price}

The National Development and Reform Commission of the State Council issued a notice about price reform of gas used by non-resident on June 28, 2013. It decided to adjust the price of natural gas used by non-resident since July 10, and liberate LNG gas source price which will be determined by supply and demand. The LNG will be mix transported in long-distance pipeline and executed the unified gate station price. The price could not be increased more than 0.4 Yuan per cubic meter in stock valve station, while the fertilizer gas price could not exceed 0.25 Yuan. The price of incremental station is 85 percent of the alternative energy price.

\section{Fuel loss affects the economy}

LNG need to be stored at low temperature $\left(-163^{\circ} \mathrm{C}\right)$ and combusted in engine after gasification (same engine as CNG engine). When the car is running, gasified gas can be consumed normally and there will be no leakage. But when parking for a long time, the gas leak from piping and valves will raise the pressure of low pressure gas container and cause danger. Therefore, a safety valve is set up on the gas container to exhaust, which result in atmospheric pollution and economic losses. International advanced technology can guarantee the gas leakage of vacuum thermal storage tanks and related accessories controlled in the safety scope. LNG daily evaporation less than $1 \%$ can ensure the container safety and protect the environment. The technology is still required to improve in this area in our country.

\section{The filling station is too little and uneven distribution}

The speed of station construction cannot catch up with the rapid growth of LNG vehicle ownership. Filling difficulty is still the biggest obstacle to promote LNG vehicle. There are 1128 LNG vehicle filling station by October 30, and most of them are distributed in southeast coastal and Xinjiang province and other places, especially along the pipeline of West-East natural gas transmission. In the vast inland regions, there is less gas station compared with the refined oil stations. This kind of situation will impact on the LNG vehicle industry development, especially the LNG trucks for long-distance transportation.

\section{Rising LNG fuel prices affect the economy}

Users not only focus on whether they can fill the natural gas, but also pay attention to the natural gas and refined oil pricing mechanism. Recently, LNG price is rising across the country. Transport 
enterprises worry most about the loss of fuel cost advantage for LNG vehicle, causing development speed of LNG vehicle slows down in some regions.

Cruising range restricts the use scope, and there are many difficulties in constructing standard station.

The cruising range of LNG vehicle is not long enough. It not only restricts the use scope of LNG vehicle, but also put forward more requirements on the construction of gas station. Therefore, the length of cruising range restricts the promotion of LNG vehicle. It is difficult to construct a gas station is the real root of 'filling gas difficulty'. Complex and cumbersome approval process let many people give up their intention to invest the construction of gas stations. The biggest bottleneck of gas station building is not money. Recently, building a new station need to be approved 26 times just in approval process. It requires a lot of manpower and time. And enterprises spent a lot money on testing and certification, which virtually set up obstacles for gas station construction and kill relevant enterprises' enthusiasm.

\section{The Development Opportunity of LNG Vehicle Filling Business}

The development opportunity of LNG vehicle filling business is mainly manifested in two aspects: market environment opportunity, and policy environment opportunity.

\section{Market environment development opportunity}

Supply and demand are prosperous in China's natural gas market since 2000. The growth speed of demand is faster than that of output. At the same time, gas imports grew rapidly. The multi-source gas supply pattern has initially formed including domestic natural gas source, importing gas through pipeline and importing liquefied natural gas (LNG) in ship. The rapid development of China's natural gas trade changed the pattern of world natural gas gradually and has injected new vitality for the world natural gas market. Especially the established Shanghai International Energy Exchange Group in Shanghai free trade zone will greatly increase the voice of our country in the international natural gas market.

\section{Policy environment development opportunity}

China's energy demand is growing fast, including natural gas, coal, renewable energy, oil and nuclear energy, but China's five-year plan calls for reducing coal consumption. In China, coal consumption accounted for $68 \%$ of primary energy consumption in 2011, but by 2035 it is expected to account for only $33 \%$. It means a lot to reduce carbon emissions. In the future, carbon dioxide emission will be more and more in non-OECD countries. In 2035, the carbon emissions standard of non-OECD countries will reach to OECD countries' emissions standard. Of course, per capita emission is different. In 2035, per capita emissions of India are still less, but China and the Middle East's per capita emissions will reach half of U.S. per capita emissions and higher than the level of Europe. And in terms of emissions' absolute value, there is no doubt that China is a huge carbon emission country. In 2012, China will emission $60 \%$ more carbon dioxide than the United States, and by 2035 China's emissions will double the emissions of United States.

In order to realize the energy structure adjustment, energy conservation and emissions reduction targets to alleviate the problem of air pollution, our country should publish relevant policy to encourage the development of natural gas industry, especially the promotion of 'converting oil to gas' policy. This will lay a good policy environment for the development of LNG vehicle filling business.

\section{The Threat for the Development of LNG Vehicles}

The threat of LNG vehicles is mainly from the new energy vehicles. CNG vehicle is a real threat. Pure electric vehicles and fuel cell vehicles are future threat. 


\section{Threat from CNG vehicles}

CNG vehicles are automobiles that used compressed natural gas (CNG) as fuel. In the case of in-use vehicle, refitting stereotyped gasoline vehicle just need to add a dedicated compressed natural gas device to form a ' $\mathrm{CNG}$ dual fuel car' under the condition of retain the original car fuel supply system. Fuel conversion just need toggle switch. Filling gas one time can travel 200 kilometers, especially suitable for buses, taxis in the city, minibuses, cars and other vehicles that a round trip mileage not more than 200 kilometers.

\section{Threat from pure electric vehicles}

In the promotion of new energy vehicles in China, pure electric drive is given priority to, and a lot of money was invested to support its development. So far, the national electric buses and passenger cars are not more than 100,000. High marketing cost becomes main obstacle of pure electric bus development. With the development of science and technology, electric car will be the most competitive threat for LNG vehicles if the key technology of large battery is conquered.

\section{Threat from fuel cell vehicles}

Fuel cell vehicle is another kind of threat. It is a technology using the reaction of hydrogen and oxygen to generate electricity. In addition to the electrical energy, only heat energy and water are produced, and there is almost no pollution to the environment. There is no battery pollution from the battery used in pure electric vehicle. In theory, it is a kind of theory that is worth promoting.

High price of fuel cell car is also a reason that it cannot commercialize. At the turn of the century, the price of a fuel cell car was more than 1 million dollars. In addition to the political purchase of government, no private would like to buy it. Of course, the price can be reduced with mass production, but the lack of infrastructure also decided it cannot be sold out. Then it has formed a circle of the chicken or the egg came first. If the relevant technologies of fuel cell car get a breakthrough, it will form a deadly fighting on LNG vehicles.

\section{Threat from regular gasoline vehicle}

Regular gasoline vehicles cannot compare with LNG vehicles on the economy and environmental performance. But it has some competitive for its convenient refuel and fuel saving. With the continuous improvement of refined oil quality and the improvement of automobile engine technology, the environmental protection of regular gasoline vehicle's tail gas will be greatly improved. According the estimation of some experts, LNG vehicle exhaust emissions and Europe VI Emission Standard don't have much advantage. Therefore, if China enforce the standard near to the Europe VI Emission Standard in the future, the threat from regular gasoline cars will become larger and larger.

\section{The Development Strategy of LNG Vehicle Filling Business}

Based on the above analysis, from the point of long-term development the development of LNC vehicle filling business should chose fast penetration strategy, namely, quickly occupying the market in the shortest time, which savings business energy for the future development of our country's cleaner energy.

\section{References}

[1]Information on http: www iangv.or5

[2]Fan Jian. The fast growth of natural gas vehicle in China make millions of units in ten years.

[OL].ChinaScience and Technology,2011.www.stdaily.com. Papergroup. content/2011-11/22. coutent388388.htm 
[3]Yan Yiping. Actively support the development of the conditional natural gas vehicle[OL]. The China association of automobile manufacturers,2011. http: www.caam.org.cn;ren/wu/ 2011/0223/1 1405052.html

[4] Zhou Shuyi, Chen Jindian,etc. The choice of natural gas vehicle development mode in China's coastal regions, J. International Petroleum Economics. 4(2010)14-19.

[5] Li Guang, Zhou Huishu , Natural-gas vehicles in China: developments and trends, J. International Petroleum Economics. 7 (2008) 69-74. 